\title{
OCENY MORALNE W ROZUMOWANIU SĘDZIOWSKIM ${ }^{*}$
}

\section{WSTĘP}

W niniejszym artykule chcielibyśmy zastanowić się nad charakterystyką rozumowania moralnego dokonywanego przez sędziów w sytuacji, gdy dochodzi do rozstrzygnięć opartych na ocenach moralnych. W szczególności chcielibyśmy odpowiedzieć na dwa pytania: czy formułowanie przez sędziów ocen moralnych wymaga od nich posiadania szczególnych kompetencji moralnych oraz czy rozumowanie moralne ma charakter rozumowania racjonalnego?

Oczywiście w kontekście zadań, jakie stawiamy sobie w niniejszym opracowaniu, nie interesuja nas zagadnienia związane $\mathrm{z}$ klasycznymi kontrowersjami co do tego, czy prawo jest w sposób nieodłączny związane z moralnościa czy też nie. Chodzi nam o rozumowanie moralne przeprowadzane w procesie uzasadniania decyzji przez sędziów w sytuacji, gdy dochodzi do rozstrzygnięć opartych na dobrach czy wartościach moralnych. Przykładowo sędzia czy filozof może rozstrzygać ten sam problem moralny, ale już odpowiedzi, jakie udzielaja, formułowane są w różnych, jak argumentował Ludwig Wittgenstein, językach.

Niewątpliwie filozofia, religia, style życia, wartości bądź standardy moralne wpływają na nasze wybory moralne, w szczególności w tak doniosłych społecznie i politycznie kwestiach, jak np. granice wolności słowa, naruszanie prywatności, czy wreszcie legalizacji dopuszczalności aborcji. Nadto jeżeli zgodzimy się, że sędziowie nie mogą nie być arbitrami moralnymi, to należałoby zwrócić uwagę na to, że ich sytuacja może różnić się ze względu na to, czy dana praktyka społeczna jest powszechnie przyjmowana przez wspólnotę polityczna, czy też jest przez tę wspólnotę odrzucana. Jeśli w danej wspólnocie politycznej panuje powszechna zgoda np. co do niedopuszczalności stosowania kary śmierci, to decyzja sądu może być uzasadniania przez odwołanie się do powszechnej społecznej aprobaty danych wartości konstytucyjnych. Wtrąćmy nawiasem, że odwołanie się do społecznego konsensusu nie zawsze jest miarodajne. Można sobie wyobrazić sytuację, w której w danej wspólnocie politycznej panuje powszechna zgoda co do dopuszczalności kary śmierci, a np. sąd konstytucyjny podejmuje decyzje o niezgodności ustawy karnej zawierającej sankcje kary śmierci z konstytucja. Zgoła odmienna sytuacja zachodzi wtedy, gdy owej powszechnej wspólnotowej aprobaty nie ma. Na przykład zgadzamy się co do społecznej/politycznej doniosłości abstrakcyjnej zasady wartości wolności słowa, ale spieramy się co do praktyki korzystania z owej wolności.

* Artykuł powstał w ramach badań finansowanych przez Narodowe Centrum Nauki (OPUS 8 2014/15/B/HS5/00650). 
Jeszcze inna sytuacja zachodzi wtedy, gdy jako wspólnota polityczna zgadzamy się co do ochrony własności, ale spieramy się co do tego, czy własność powinna być opodatkowana. Wreszcie ostatnia sytuacja występuje wtedy, gdy wspólnota polityczna pozostaje w radykalnej w niezgodzie co do rozwiązania problemu o podłożu moralnym, np. co do legalizacji dopuszczalności aborcji. W takiej sytuacji każda decyzja sądu może prowadzić do wojny ideologiczno/ moralnej owej wspólnoty ${ }^{1}$.

\section{USTALENIA TERMINOLOGICZNE}

Mając na uwadze wyżej wymienione sytuacje, pytanie o podstawy formułowania przez sędziów ocen moralnych jawi się jako kluczowe. Zanim przejdziemy do odpowiedzi na to pytanie, w pierwszym rzędzie należałoby dokonać pewnych uściśleń terminologicznych. Po pierwsze, rozumowanie moralne jest szczególnym przypadkiem rozumowania praktycznego. Po drugie, termin „rozumowanie sędziowskie" oznacza proces uzasadniania decyzji dokonywanych przez sędziów. Podstawową typologia rozumowania moralnego jest typologia opierająca się na przeciwstawieniu rozumowania teoretycznego rozumowaniu praktycznemu. Zadaniem teoretycznego rozumowania moralnego jest czysty opis danych, którymi są reguły prawne bądź fakty. Natomiast praktyczne rozumowanie moralne to uzasadnienie decyzji. Rozumowanie, które spełnia warunki rozumowania praktycznego, to rozumowanie moralne, jego podstawowym zadaniem jest bowiem uzasadnienie decyzji ${ }^{2}$.

Jak wiadomo, zarówno moralne, jak i sędziowskie rozumowania moga przyjmować różną postać. Na przykład moralne oraz sędziowskie rozumowania jako rozumowania dedukcyjne są trywialne. Na ich podstawie można zbadać wyłącznie formalna poprawność rozumowania. Odnosiłyby się jedynie do uzasadniania wewnętrznego, czy też racjonalności wewnętrznej rozumowań moralnych oraz sędziowskich. Zasadniczym a zarazem znacznie trudniejszym zagadnieniem jest natomiast uzasadnienie zewnętrzne (racjonalność zewnętrzna), odnoszące się do kwestii doboru oraz prawdziwości przesłanek w przeprowadzanym rozumowaniu moralnym czy sędziowskim. Dlatego adekwatne przeprowadzenie rozumowania moralnego i sędziowskiego winno dążyć do wykazywania racji na rzecz przyjmowania określonego rozstrzygnięcia. Wtraćmy nawiasem, że w szczególności powołanie na rację publiczna (public reason) jest o tyle doniosłe, że pozwala na racjonalizowanie procesu podejmowania decyzji.

Niektórzy autorzy przyjmuja, że rozumowanie moralne wymaga od sędziów posiadania szczególnych kompetencji moralnych. Przypomnijmy w tym miejscu znany sylogizm Jeremy'ego Waldrona:

${ }^{1}$ S. Mancini, M. Rosenfeld, The Judge as Moral Arbiter? The Case of Abortion (January 7, 2010), w: A. Sajó, R. Uitz (eds.), Constitutional Topography: Values and Constitutions, Boom Eleven International, 2010. Dostępne na stronie internetowej, SSRN: https://ssrn.com/abstra$\mathrm{ct}=1721644$.

${ }^{2}$ Zob. szerzej J. Wróblewski, Presupozycje rozumowania prawniczego, „Studia Prawno-Ekonomiczne" 37, 1986, s. 9-11. 
1. Każda decyzja odwołująca się do praw konstytucyjnych wymaga odwołania się do argumentów moralnych.

2. Sędziowie, uzasadniając decyzję na podstawie argumentacji moralnej, powinni posiadać szczególne kompetencje moralne.

3. Dlatego na sędziach ciąży szczególna odpowiedzialność za podejmowanie decyzji, w których odwołują się do praw konstytucyjnych ${ }^{3}$.

Nawiasem mówiąc, Wojciech Sadurski kwestionuje przesłankę pierwszą wskazująca, że decyzja odwołująca się do praw konstytucyjnych wymaga odwołania się do argumentów moralnych. Jego zdaniem w żadnym wypadku decyzja sędziego nie jest bardziej moralna aniżeli decyzje podejmowane np. przez organy administracji publicznej czy przez prawodawcę. Oczywiście decyzje sędziów moga być oparte na jakoś pojmowanej psychologii moralności, prawodawcy zaś mają inklinację do myślenia abstrakcyjnego opartego na pojęciach czy zasadach. Ale nie jest to podstawa do uznania, że formułują oceny moralne w sposób lepszy aniżeli inne podmioty działajace w sferze publicznej" ${ }^{4}$.

W powyższym sylogizmie kwestionujemy druga przesłankę. W sytuacji podejmowania decyzji, w której sędziowie odwołują się do praw konstytucyjnych, przyjmujemy, że nie charakteryzują się oni jakimiś szczególnymi kompetencjami moralnymi do rozstrzygania dylematów moralnych aniżeli inne podmioty, np. legislatorzy. Oczywiście właściwe rozpoznanie i uzasadnianie praw konstytucyjnych wiąze się z moralnym rozumowaniem, ale to rozumowanie sędziów nie jest bardziej moralne aniżeli rozumowanie innych podmiotów działających w sferze publicznej. Nie jest też bardziej moralne od rozumowań niezorientowanych na artykulację praw konstytucyjnych. Nie można się również zgodzić z poglądem, jakoby sędziowie posiadali szczególne kompetencje moralne wynikające z praktyki sędziowskiej, tj. ciagłego rozstrzygania problemów moralnych, i stąd charakteryzowali się szczególną umiejętnością empatii czy wczuwania się w realne problemy ludzi. Ten typ uzasadniania szczególnych kompetencji moralnych sędziów, oparty na ich doświadczeniu i odwołujący się do faktycznych jednostkowych sytuacji, nie ma żadnych podstaw empirycznych ${ }^{5}$. Nie ma też żadnych podstaw, by sądzić, że moralne eksperymenty myślowe, które nieodłącznie pojawiają się w pracy umysłowej sędziego wtedy, gdy rozstrzyga spory faktyczne, są szczególnie uprzywilejowane w stosunku do tzw. abstrakcyjnego rozumowania moralnego opartego na zasadach czy wartościach. Przekonujących argumentów na rzecz przyjęcia takiego stanowiska dostarczaja psychologia moralności i kognitywistyka, a zwłaszcza ich ostatnie ustalenia ${ }^{6}$.

${ }^{3}$ J. Waldron, Judges as moral reasoners, „International Journal of Constitutional Law” 7(1), 2009, s. 2-24.

${ }^{4}$ W. Sadurski, Rights and moral reasoning: an unstated assumption - a comment on Jeremy Waldron's “Judges as moral reasoners”, „International Journal of Constitutional Law” 7(1), 2009, s. $25-45$.

${ }^{5}$ Ibidem.

${ }^{6}$ Pewną nadzieję daje w tej mierze rozumowanie oparte na Rawlsowskiej refleksyjnej równowadze. Termin „reflective equilibrium” wprowadzony przez J. Rawlsa oznacza równowagę pomiędzy zasadami ogólnymi a konkretnymi ocenami uznawanymi przez jednostkę. Równowaga powstaje w ten sposób, że jednostka stara się dopasować do siebie zasady i konkretne oceny. Jeśli 


\section{OCENY MORALNE W UJĘCIU PSYCHOLOGICZNYM}

Gdy ludzie dokonuja ocen moralnych, opieraja się na przyjętych przez siebie zasadach moralnych, które są powszechnie uważane za uniwersalne. Na co dzień zazwyczaj nie dochodzi do rażącego pogwałcenia tych reguł (tzw. fundamentów moralnych), a raczej do ich naciagania. Problem taki można rozwiązać przez odwołanie się do innych reguł bądź konsekwencji, do jakich może dochodzić z uwagi na takie nieznaczne naruszenie zasady moralnej. Rozwiązywanie drobnych problemów moralnych odbywa się na podstawie rozumowania.

Powstaje jednak pytanie, czy podczas rozwiązywania dylematów moralnych sędziowie wykorzystuja rozumowanie abstrakcyjne, jak podczas rozwiązywania zwykłych problemów, czy raczej podejmują emocjonalno-społeczne decyzje. Czy rozumowania moralne służą poszukiwaniu prawdy, czy są zwyczajnym poszukiwaniem racjonalnego uzasadnienia reakcji emocjonalnych, argumentów, które by uzasadniły dokonana wcześniej ocenę? Jest to pytanie szczególnie doniosłe w przypadku sędziów, których istota pracy jest dokonywanie rozstrzygnięć zgodnie z normami i od których oczekuje się racjonalnego rozumowania, a nie szybkiego i intuicyjnego podejmowania decyzji.

Rozumowanie jest spostrzegane jako proces, dzięki któremu rozwijamy naszą wiedzę i podejmujemy bardziej wartościowe decyzje, w rzeczywistości często wiedzie nas na manowce i jest podstawą błędnych decyzji. Od ponad pół wieku psychologia dostarcza dowodów, że ludzie nie rozumuja najlepiej, nie radząc sobie z prostymi zadaniami logicznymi, popełniaja poważne błędy w probabilistycznym rozumowaniu i są podatni na liczne zniekształcenia przy podejmowaniu decyzji, tymczasem prawnicy bardzo często przyjmuja, że ludzie są racjonalnymi jednostkami, które maksymalizują oczekiwaną użyteczność, działaja, opierajac się na swoich preferencjach, obliczaja prawdopodobieństwa zgodnie z regułą bayesowską i mają przed sobą jasne cele, którymi się kierują. Sędziowie, $\mathrm{w}$ tym podejściu, sa jednostkami w pełni racjonalnymi ${ }^{7}$.

W racjonalizmie najważniejszy jest rozum, który operuje, opierając się na wiedzy, informacjach, doświadczeniu, ale też emocjach (racjonalizm traktuje emocje jako ważną część ludzkiej natury i dopełnienie intelektu) w poszukiwaniu prawdy, by ludzie mogli ocenić i wybrać akceptowane normy moralne, by

\footnotetext{
konkretne oceny kłócą się z uznanymi zasadami, musi ona zmienić jedne lub drugie i w ten sposób osiagnąc równowagę. Warto przy tym zauważyć, że jeśli porównamy refleksyjną równowagę $\mathrm{w}$ dogmatyce prawa $\mathrm{z}$ podobną refleksją w filozofii moralnej, uderzy nas także, że prawnik musi przywiązywać większą rolę do tekstów i praktyk prawnych niż filozof moralny. Ten ostatni może na przykład na serio dyskutować problem, czy powinno się przestrzegać konstytucji. Dla prawnika jednak ten problem jest poza horyzontem dyskusji. Nie można sobie na przykład wyobrazić adwokata, który by przed Trybunałem Konstytucyjnym argumentował za teza, że konstytucja nie jest wiążąca. Prawnicza równowaga refleksji jest więc szeroka, ale ograniczona horyzontem prawniczym. Szerzej: M. Smolak, The method of reflective equilibrium in moral reasoning, „Archiwum Filozofii Prawa i Filozofii Społecznej” 2015, nr 1, s. 89-96.

${ }^{7}$ Zob. szerzej: T. Pietrzykowski, Intuicja prawnicza. W stronę zewnętrznej integracji teorii prawa, Warszawa 2012.
} 
wiedzieli, jak się zachowywać i - ze względu na argumenty przemawiające przeciwko pewnym zachowaniom - by potępiali osoby postępujące niewłaściwie. To, czy jakiś czyn jest etycznie dobry czy zły, zdaniem wielu filozofów (jak np. św. Tomasz z Akwinu czy Immanuel Kant) zależy od tego, czy jest zgodny z rozumem. Z kolei filozofowie oświeceniowi (np. David Hume, Adam Smith) twierdzili, że nasze oceny moralne nie są efektem racjonalnej dedukcji, logicznego wnioskowania i przy powstawaniu norm moralnych dawali pierwszeństwo emocjom, uczuciom moralnym. W psychologii można spotkać się również ze zwolennikami poglądu, że rozumowanie to najlepsza droga ku wiedzy moralnej. Przykładem moga być poglądy Jeana Piageta, który zauważał, że do moralności dorastamy tak jak do racjonalności, czy Lawrence'a Kohlberga, który opracował teorię rozwoju moralnego i za Piagetem twierdził, że w kolejnych fazach rozwoju dzieci zaczynają coraz lepiej rozumieć powody przestrzegania norm moralnych i tworzą własny, spójny system moralny, na podstawie pogłębiającego się rozumienia $\mathrm{krzywdy}^{8}$. Badania przeprowadzone w ostatnich latach podważają te założenia, np. pokazuja, że dzieci reagują na naruszenie zasad już w wieku trzech lat, a nawet jeszcze wcześniej, jeszcze zanim pojawi się język i myślenie ${ }^{9}$.

Indywidualny wkład psychologii w dyskusję na temat racjonalności rozumowania dotyczy przede wszystkim problematyki błędów i pułapek oceniania oraz procesu podejmowania decyzji (szczególnie zniekształceń przy ich podejmowaniu), wiedza ta ma też zastosowanie przy analizie rozumowania moralnego sędziów ${ }^{10}$. Utylitaryzm definiuje moralne działania jako takie, które maksymalizują użyteczność dla grupy, celem wszelkiego działania powinno być maksymalizowanie dobra, nawet jeśli kilka jednostek doznałoby przy tym krzywdy. W ten sposób podejście to jest zbliżone do bardziej współczesnych teorii ekonomicznych oczekiwanej użyteczności, czy znanych na gruncie psychologii zarządzania analiz wkład-wynik (np. koncepcje motywacji: teoria równowagi pomiędzy wysiłkiem a nagrodą lub teoria słuszności). Czy ludzki umysł działa jak komputer? Psychologia pokazała słabość teorii ekonomicznych wykorzystywanych do analiz decyzji moralnych, opierających się na założeniu, że decydent dokonuje optymalizacji, a proces ten można opisać za pomoca matematycznego wzoru (optymalizacja polega np. na tym, w jaki sposób poprawić los jednostek tak, aby nikt na tym nie ucierpiał). Liczne prace z zakresu psychologii decyzji (nawet gdy decyzje nie dotyczą problemów moralnych) pokazują, że decyzje podejmowane przez ludzi znacznie odbiegają od optymalnego, racjonalnego procesu i że opieramy się na heurystykach oraz podlegamy iluzjom. Najlepszym tego przykładem moga być prace Daniela Kahnemana i Amosa Tversky'ego, za ich wieloletnie badania eksperymentalne i przemyślenia, które podważyły model racjonal-

\footnotetext{
${ }^{8}$ Por. L. Kohlberg, The child as a moral philosopher, „Psychology Today” 1968, September, s. 25-30. Także: M. Smolak, Spoteczeństwo sprawiedliwe wedtug Lawrence’a Kohlberga, „Problemy Rozwoju Edukacji” 1992, z. 1, s. 36-47.

${ }^{9}$ Zob. V. LoBue, T. Nishida, C. Chiong, J. S. DeLoache, J. Haidt, When getting something good is bad: even three-year-olds react to inequality, „Social Development” 20(1), 2011, s. 154-170.

${ }^{10}$ Por. T. Tyszka, Decyzje - perspektywa psychologiczna i ekonomiczna, Warszawa 2010.
} 
ności ludzkich osądów i decyzji Kahneman otrzymał w 2002 r. Nagrodę Nobla w dziedzinie ekonomiii ${ }^{11}$.

Jak zauważył Tadeusz Tyszka, pojęciu „decyzja” towarzyszy najczęściej określenie „racjonalna” lub „nieracjonalna”, chcielibyśmy oczywiście, by nasze decyzje były racjonalne i zwykle za takie je uważamy. Jakość decyzji oceniamy zwykle przez jej skutki, chociaż jakość wyników podjętej decyzji wiąże się jednak z racjonalnością wyboru, to taki sam skutek może być efektem nierozsądnej decyzji (a także niektóre decyzje podejmowane starannie i rozważnie moga mieć opłakane skutki). O racjonalności decyzji przesądza zatem strategia decyzyjna (jakość sposobu postępowania). To, jakie strategie decyzyjne są optymalne w różnych sytuacjach decyzyjnych, opisują teorie normatywne. Na przykład gdy mamy do czynienia ze skomplikowanym problemem decyzyjnym, racjonalny proces podejmowania decyzji polegałby na określeniu procesu decyzyjnego, a następnie na uważnym przeanalizowaniu racji za i przeciw. Mogłoby to polegać na narysowaniu tzw. drzewa decyzyjnego, które ułatwiłoby prześledzenie takiego procesu. Na diagramie należałoby umieścić alternatywy wyboru, konsekwencje tych działań oraz ewentualne uwarunkowania tych konsekwencji, a racjonalność wyboru polegałaby na decyzji dotyczącej działania prowadzacego do optymalnego skutku. Normatywna teoria decyzji zakłada, że wybory dokonywane przez decydentów są na ogół racjonalne, pozwala to zbudować funkcję użyteczności, co w praktyce umożliwia wspomaganie decydentów w jego wyborach.

Możemy jednak zauważyć, że preferencje ludzi nie zawsze są zgodne, są też niestabilne, należałoby zatem powiedzieć, że naruszają postulaty racjonalności. Powstaje pytanie, w jakich warunkach do tego dochodzi. Wiedza na temat tego, w jaki sposób ludzie rzeczywiście podejmują decyzje, należy do opisowej teorii decyzji, która w zasadzie obowiązuje we współczesnej psychologii.

Warto to zilustrować przykładem badań przeprowadzonych przez Donalda E. Redelmeiera i Daniela Kahnemana, które dotyczą zapamiętywania bolesnych procedur medycznych. Pamięć o przebiegu pewnych zabiegów może wpływać na przyszłe decyzje pacjentów, może np. skutkować unikaniem kolejnych badań, mimo iż są zalecane. Autorzy ci zauważyli, że pamięć ta nie jest dokładna i jest podatna na zniekształcenia. Analizowali to w odniesieniu do mało inwazyjnych, aczkolwiek bolesnych zabiegów, jakimi są kolonoskopia oraz litotrypsja (usuwanie kamieni). Podczas zabiegu pacjenci udzielali informacji na temat intensywności doznań bólowych, a następnie dokonywali retrospektywnej oceny bolesności całego zabiegu. Porównanie tych ocen pozwoliło zauważyć, że ogólne oceny dokonywane przez osoby badane były wypadkową dwóch czynników: szczytowej intensywności natężenia bólu oraz oceny intensywności dokonywanej w ostatniej fazie zabiegu (ostatnich 3 minutach), były natomiast niezależne od czasu trwania zabiegu, pomimo iż czas ten był bardzo zróżnicowany u poszczególnych pacjentów (od kilku minut do ponad godziny). Badani uśredniali najbardziej intensywne doznanie bólowe z doznaniem końcowym, w związku z czym oceny bolesności były wyższe

\footnotetext{
${ }^{11}$ Przegląd tych badań oraz podobne analizy można znaleźć w pracach T. Tyszki, np. ibidem.
} 
w przypadku, gdy nieprzyjemne doznania rosły w trakcie zabiegu w porównaniu z sytuacja, gdy najbardziej intensywne doznanie było podobne, a czas trwania nieprzyjemnych doznań był nawet dłuższy, jednak natężenie doznań malało w czasie zabiegu, by zakończyć się mniejszym dyskomfortem. W tym przypadku długość trwania zabiegu (i cierpienia) nie miała znaczenia ${ }^{12}$.

Liczne badania eksperymentalne prowadzone przez psychologów pokazuja, że uzyskanych wyników nie można wytłumaczyć w ramach klasycznej koncepcji użyteczności, zaproponowano więc teorię użyteczności doświadczanej, uwzględniająca subiektywne odczucia jednostki, co w końcu doprowadziło do powstania behawioralnej teorii decyzji. Wyniki tych badań, prowadzonych od kilkudziesięciu już lat, pokazuja, że decydenci na ogół są dalecy od racjonalności. Na przykład rzadko nam przychodzi do głowy to, że istnieją różne perspektywy poza tą, która nam się aktualnie narzuca, a gdy już sformułujemy problem decyzyjny, to nasuwają nam się tylko nieliczne alternatywy wyboru (a i tak mamy skłonność do nadmiernego redukowania ich zbioru). Do podjęcia decyzji, którą można by było uznać za racjonalna, brakuje nam często informacji (informacji o sytuacji, o kosztach związanych z wyborem każdej z alternatyw, o potencjalnych konsekwencjach podjętych działań itd.), nie tylko dlatego, że te informacje są niedostępne, ale przede wszystkim dlatego, że nie angażujemy się w ich poszukiwanie ${ }^{13}$. A nawet gdyby te informacje były łatwo dostępne, to i tak mamy ograniczona pojemność informacyjną i musimy dokonywać redukcji nadmiaru tych informacji. Czy sędziowie dysponuja wszystkimi niezbędnymi informacjami, potrzebnymi do tego, by móc uznać ich rozstrzygnięcia za racjonalne (przy założeniu, że spełnione są pozostałe warunki)?

W procesie tym wykorzystujemy również informacje wewnętrzne - dysponujemy bowiem informacjami przechowywanymi w pamięci, a nawet całościowe oceny poszczególnych alternatyw, ale dostęp do tych informacji jest zróżnicowany (np. łatwiejszy jest dostęp do informacji częściej powtarzanych bądź gdy informacja jest świeża, czy ważniejsza). Ludzie mają kłopoty nie tylko z wydobywaniem tych informacji z pamięci, ale też z tym, że informacje te podlegają różnym deformacjom, np. zapamiętujemy tylko ogólne określenia, uproszczone podsumowania, a nie pamiętamy szczegółów. Ba, możemy nawet pamiętać zdarzenia, które nigdy nie miały miejsca (tzw. fałszywa pamięć), ponieważ nasza pamięć ma charakter konstrukcyjny, a przypominanie nie polega na prostym wydobywaniu wcześniej zapamiętanych informacji, ale obejmuje procesy wnioskowania i rozwiązywania problemów, skoro więc pamiętamy tylko ogólną ideę, szczegóły sobie rekonstruujemy, a zdarzenia, w których nie braliśmy udziału, możemy po prostu sobie wywnioskować. Z tego, że należy zachować ostrożność wobec tego, co ujawnia ludziom pamięć, powinni zdawać

${ }_{12}$ Zob. D. A. Redelmeier, D. Kahneman, Patient's memories of painful medical treatments: real-time and retrospective evaluations of two minimally invasive procedures, „Pain” 66(1), 1996, s. 3-8.

${ }^{13} \mathrm{~W}$ takich sytuacjach mówimy o ekonomii poszukiwania informacji, która dotyczy kosztów starannego zbierania danych przed podjęciem decyzji. 
sobie sprawę prawnicy uczestniczący w postępowaniu sądowym, w trakcie którego wykorzystuje się zeznania świadków.

Poza tym na ograniczoną racjonalność procesu podejmowania decyzji wskazuje też fakt, że ludzie nie wykorzystują w pełni informacji, a zwłaszcza nieprawidłowo szacują prawdopodobieństwa zdarzeń. Klasyczne badania A. Tversky'ego i D. Kahnemana pokazały, że ludzie kierują się podczas dokonywania ocen heurystykami, które wprawdzie mogą być użyteczne, ale sa uproszczonymi metodami wnioskowania i nie dają gwarancji pewności. W niektórych sytuacjach moga prowadzić do wyolbrzymiania albo zaniżania oceny prawdopodobieństwa i moga prowadzić do systematycznego popełniania błędów. W jednym z takich badań autorzy ci przedstawili badanym zadanie oszacowania prawdopodobieństwa wypadnięcia określonej sekwencji podczas sześciokrotnego rzutu moneta. Ludzie oceniali jako najbardziej prawdopodobny rezultat O-R-R-O-O-R, mniej prawdopodobny O-O-O-R-R-R, a najmniej prawdopodobną sekwencję O-O-O-O-R-O, która nie odzwierciedla „sprawiedliwości” monety. Prawdopodobieństwo każdej z tych sekwencji jest we wszystkich tych przypadkach, oczywiście, takie samo, ponieważ za każdym razem prawdopodobieństwo wypadnięcia orła bądź reszki wynosi 0,5, rzuty sa niezależne, a moneta, jak celnie zauważył T. Tyszka, nie ma pamięci. Błąd ten wynika z posługiwania się przez ludzi heurystykami, w tym przypadku heurystyką reprezentatywności, która polega na tym, że prawdopodobieństwo oceniamy na podstawie tego, w jakim stopniu zdarzenie jest podobne do populacji, z której pochodzi. W ten sposób ignorujemy ogólne prawidłowości, a nasze myślenie nie przebiega zgodnie z prawami logiki formalnej, tylko oceniamy prawdopodobieństwo wystapienia zdarzeń przez pryzmat zgodności z naszymi wyobrażeniami ${ }^{14}$.

Weźmy pod uwagę na przykład problem, jaki mają sędziowie z przyjmowaną zasadą in dubio pro reo (nie można skazać oskarżonego, jeżeli pozostaje jakakolwiek racjonalna wątpliwość co do jego winy). Określenie tego, co oznacza dla sędziego stwierdzenie „ponad wszelką wątpliwość”, wymagałoby od sędziego dokonywania skomplikowanych obliczeń prawdopodobieństwa winy oskarżonego, uwzględniajacc cztery rodzaje konsekwencji związanych z tą decyzją: użyteczność skazania winnego, użyteczność (negatywna) skazania niewinnego, użyteczność (negatywna) uniewinnienia winnego oraz użyteczność uniewinnienia niewinnego. Punkt, w którym sędzia znajduje się na granicy pomiędzy decyzją skazać czy uniewinnić, zależy od tego, w jaki sposób sędzia wartościuje te cztery konsekwencje (ich użyteczność) ${ }^{15}$.

O racjonalności (bądź nie) procesu podejmowania decyzji świadczy też to, w jaki sposób przebiega wnioskowanie. Konsekewncje podjętych działań nie sa, z natury rzeczy, nam dostępne, wnioskowanie pozwala nam uzyskać przekonanie na temat tych niedostępnych cech alternatyw. Wytwarzamy te przekonania odwołując się do swoich doświadczeń lub opierając się na uznawanych teoriach. Na przykład obserwujemy współwystępowanie zjawisk (ko-

${ }_{14}$ Zob. D. Kahneman, A. Tversky, Subjective probability: a judgment of representativeness, „Cognitive Psychology” 3, 1972, s. 430-454.

15 T. Tyszka, op. cit. 
relację) i następnie wystapienie jednej z cech wywołuje przekonanie, że pojawi się druga (np. kojarzymy wysoką cenę z jakościa, więc gdy coś jest drogie, wnioskujemy, że musi być dobre). Gdy opieramy się na niewielkiej liczbie obserwacji, wnioskowanie o związku przyczynowo-skutkowym pomiędzy dwoma zdarzeniami tym bardziej może być zawodne. Podobnie wiara w naiwne, zdroworozsądkowe teorie opiera się na skłonności do dostrzegania zależności pomiędzy zjawiskami, które nie występują (tzw. pozorna korelacja). Dlatego więc komisja, która podejmuje decyzje o warunkowym zwolnieniu skazanego, nie może opierać się na jednostkowych informacjach o popełnionych przez przedterminowo zwolnionych osadzonych przestępstwach, tj. zamiast na podstawie medialnych doniesień na temat ostatnich zdarzeń o niewielkim zakresie - komisja powinna brać pod uwagę częstotliwość popełniania przestępstw przez wszystkich zwalnianych warunkowo (a najlepiej jeszcze przy uwzględnieniu danych społeczno-demograficznych, czyli częstotliwość popełnianych przestępstw przez osoby zwalniane warunkowo, które np. są bezdomnymi mężczyznami po 50 roku życia $)^{16}$.

Co zatem nam pozostaje, jeżeli odrzucimy założenie o racjonalności ocen moralnych? Niektórzy filozofowie wskazywali na intuicje. Intuicjonistyczne podejście do moralności, które uwzględnia kontekst społeczny prezentuje np. Jonathan Haidt. Autor twierdzi, że kult rozumu jest złudzeniem - nasze świadome rozumowanie (strumień słów i obrazów, których jesteśmy świadomi) to tylko jeden procent naszych procesów psychicznych, pozostałe to procesy, które przebiegają poza świadomością i które determinuja większość naszych zachowań. Haidt prezentuje model zgodny z ideą Hume’a, że najważniejszym źródłem ocen moralnych są intuicje, zdaniem Haidta źródłem moralności sa czynniki wrodzone i społeczne uczenie się. Czynniki wrodzone to zbiór intuicji moralnych, które ukształtowały się ewolucyjnie, jest to naturalna skłonność do moralizowania. Intuicje moralne to szybkie, nie wymagające wysiłku oceny moralne, których dokonujemy każdego dnia, większość z nich nie osiaga nawet poziomu emocji moralnych. A ponieważ przypadki naruszania konwencji społecznych mogą być w innych kulturach traktowane jako wykroczenia moralne, Haidt dodawał, że ludzie uczą się stosowania intuicji moralnych w obrębie swojej kultury (chociaż wskazywał też na to, że większym niż efekt kultury może być efekt klasy społecznej). Autor ten przez wiele lat prowadził badania, które zainspirowały wielu psychologów. W ich trakcie przedstawiano osobom badanym historyjki związane np. z naruszaniem zasad moralnych (tzw. fundamentów moralnych), opisywane były w nich przypadki niekrzywdzącego innych naruszania norm. Następnie proszono o ich ocenę oraz podanie uzasadnienia tej oceny. Opisywane sytuacje miały za zadanie wywoływać u badanych odrazę, bez wskazywania ofiary, która doznawała w wyniku takiego zachowania krzywdy, tak aby badani nie mogli uzasadnić potępienia moralnego. Historyjki te dotyczyły ludzi, którzy robią coś obrzydliwego, hańbiącego (np. odbywanie stosunku płciowego z kupionym $\mathrm{w}$ supermarkecie kurczakiem przed upieczeniem go w piekarniku i zjedzeniem, czy uprawianie seksu pomiędzy

${ }^{16}$ Interesujące przykłady związane z procesami podejmowania decyzji przedstawia T. Tyszka w książce Psychologiczne pułapki oceniania i podejmowania decyzji, Gdańsk 1999. 
dorosłym rodzeństwem), lub świadczącego o braku szacunku (np. czyszczenie toalety pociętą na kawałki flaga państwowa). Osoby przedstawiane w historyjkach robiły to jednak na osobności i w ten sposób nie mogły obrażać uczuć innych osób. Dodatkowo Haidt zadawał jeszcze pytanie, czy ktokolwiek ucierpiał wskutek tego, co zrobił bohater historyjki, by kontrolować wpływ spostrzeganej krzywdy. Wyniki pokazały, że badani dokonywali ocen moralnych szybko i emocjonalnie, ale nie mogli z łatwością wyjaśnić swoich intencji moralnych. Tę niezdolność do wyjaśnienia w sposób werbalny tego, czego byli intuicyjnie pewni, Haidt nazwał „osłupieniem moralnym”. W innych badaniach eksperymentator próbował wpłynać na zmianę ocen, podając argumenty za tym, że jest to tylko naruszenie konwencji, ponieważ nikt na tym nie ucierpiał, bądź wykazując błędy logiczne w podawanych przez osoby badane uzasadnieniach. Badani pozostawali jednak przy swoich ocenach, byli ich pewni, mimo iż nie potrafili wskazać racjonalnego uzasadnienia sformułowanej wcześniej oceny i często odwoływali się do odczuwanych emocji (np. wstręt). Wskazywać to może na to, że oceny moralne są tworzone w automatyczny sposób, bez udziału kontrolowanego poznania ${ }^{17}$.

Rozumowanie moralne, zdaniem J. Haidta, jest „sługą emocji moralnych”. Autor ten zatytułował jeden ze swoich esejów Emocjonalny pies i jego racjonal$n y$ ogon, używając tej metafory w celu zobrazowania, iż rozumowanie moralne służy przede wszystkim poszukiwaniu argumentów, które by uzasadniały sformułowaną wcześniej opinię, potwierdzały reakcje emocjonalne badanych. Takie wymyślanie po fakcie dokonywane jest, zdaniem Haidta, po to, by racjonalnie uzasadnić instynktowne odczucia. Zwracał na to wcześniej uwagę Howard Margolis, który twierdził, że nasz umysł nie działa jak komputer, gotowe oceny są wytwarzane przez „nieświadomą maszynerię mózgu”, a uzasadnienia są tylko sformułowanymi po fakcie racjonalizacjami ${ }^{18}$.

Sądy moralne nie są zwykłymi opiniami, ponieważ zawierają stwierdzenie, że ktoś inny uczynił coś złego, to należy wskazać na coś, co wykracza poza nasze osobiste preferencje. W takim przypadku musimy odwołać się do rozumowania moralnego. Jednak, jak przekonuje J. Haidt, w rozumowaniu moralnym nie chodzi tak naprawdę o odtworzenie rzeczywistych powodów, dla których dana osoba sformułowała taka, a nie inną ocenę moralna, ale o to, by znaleźć takie powody, dla których inni zgodzą się z naszą opinią.

Hugo Mercier i Dan Sperber postuluja, by przemyśleć, jakie funkcje spełnia rozumowanie moralne, i sugerują że jest to funkcja argumentacyjna, rozumowanie następuje zazwyczaj po sformułowaniu oceny i służy uzasadnianiu w celu wywarcia wpływu na innych. Ma to podłoże ewolucyjne - argumentujemy post hoc z uwagi na to, że musimy dbać o swoją reputację, chcemy zawierać sojusze i zyskiwać przychylność innych członków grupy. Nie powinniśmy zatem od ludzi oczekiwać, jak dodaje J. Haidt, poprawnego, bezstronnego i dążącego do prawdy rozumowania, zwłaszcza w sytuacjach, gdy w grę wchodzi ich

${ }_{17}$ Zob. J. Haidt, Prawy umyst. Dlaczego dobrych ludzi dzieli religia i polityka?, Sopot 2014.

${ }_{18}$ Zob. szerzej: H. Margolis, Patterns, Thinking and Cognition. A Theory of Judgment, Chicago 1990. 
interes, rozumowanie moralne jest ukształtowaną ewolucyjnie umiejętnościa, która służy realizacji celów społecznych ${ }^{19}$.

Koncepcje wyjaśniające, w jaki sposób ludzie dokonują rozstrzygnięć moralnych, podkreślają wpływ rozumu bądź emocji. Ostatnie dekady przyniosły, jak widać na podstawie powyższych rozważań, liczne dowody, które skłaniaja psychologów do wyzwolenia się spod dominacji racjonalizmu i przychylania się jednak do tego drugiego poglądu filozofów. Coraz częściej wskazuje się na to, że oceny moralne mogą być związane przede wszystkim z odczuwanymi przez nas emocjami, jakie wzbudza w nas obserwacja zachowania niezgodnego z normami (w danej kulturze). Badania na ten temat dodatkowo były inspirowane i wspierane analizami neurobiologicznymi, które okazały się pomocne zwłaszcza przy rozstrzyganiu sporu „serce czy rozum” (tj. afekt czy poznanie). Ożywiło to też normatywne debaty etyczne na temat naszych powinności wobec siebie i innych.

W psychologii moralności widać tutaj wyraźny wpływ filozofii, który ukształtował sposób myślenia o problemach moralnych, w dyskusji dominuja dwa główne ujęcia: utylitaryzm i deontologia. Debata filozoficzna dotycząca tego, na jakich zasadach powinniśmy opierać nasze oceny moralne, zainspirowała wielu psychologów do prowadzenia badań nad procesem oceny moralnej, obecnie te normatywne ujęcia stanowia podstawę ewaluacji dokonywanych ocen i decyzji moralnych. Możemy spotkać się też z wynikami badań psychologicznych, które pokazuja, że ludzie przyjmują postawę utylitarną bądź deontologiczną w zależności od różnych czynników. Czy oceny dokonywane na podstawie zasad utylitarnych różnią się w jakościowy sposób od tych dokonywanych na podstawie zasad deontologicznych? I czy badania nad błędami poznawczymi czy stosowaniem heurystyk w obszarze podejmowania decyzji pozwalają na taką odpowiedź?

W badaniu tego, w jaki sposób ludzie dokonują ocen moralnych, wykorzystuje się często dylematy moralne. Przy ich rozwiązywaniu, jak pokazują badania neurobiologów, aktywacji ulegają różne części mózgu, udział biorą zarówno procesy poznawcze, jak i emocjonalne. Najbardziej znane są dylematy wagonika i mostka, choć sa one wykorzystywane w licznych modyfikacjach, ogółem rzecz biorąc sprowadzają się do problemu, czy można poświęcić życie jednej osoby, by uratować pięć innych. Pierwszy z tych dylematów dotyczy sytuacji, w której (badany ma to sobie wyobrazić) po szynach nadjeżdża rozpędzony wagonik, a zwrotnica jest ustawiona w taki sposób, że wagonik uderzy w pięć nieznanych osób stojących na torze i zabije wszystkich, jeśli badany nic nie zrobi. Można jednak ich uratować, przestawiając zwrotnicę, tyle tylko, że skieruje to wagonik na boczny tor, na którym stoi jeden człowiek, również nieznany i nie wiedzący nic o grożącym niebezpieczeństwie. Jeżeli przestawi się zwrotnicę, by uratować pięć osób, ten człowiek zginie. Jak postapić w takiej sytuacji? Dylemat mostka przedstawia podobna sytuację z rozpędzonym wagonikiem i pięcioma nieświadomymi osobami na jego torze, z tą różnica,

${ }^{19}$ Ewolucjoniści podkreślają rolę grupy społecznej dla funkcjonowania człowieka, zob. szerzej: H. Mercier, D. Sperber, Why do humans reason? Arguments for an argumentative theory, „Behavioral and Brain Sciences" 34(2), 2011, s. 57-74. 
że tor biegnie pod wiaduktem, na którym stoi badany. Obok niego na mostku stoi nieznany człowiek, podobny do tych stojących na torach osób. Jeżeli zepchnie się go na tor, jego ciało zatrzyma wagonik i ocali to życie pięciu osób, z tym że ten człowiek z pewnością zginie. Co należy zrobić? Wyniki badań z wykorzystaniem tych dylematów pokazały, że w pierwszym przypadku większość ludzi wybiera przestawienie zwrotnicy. Jest to rozwiązanie utylitarne, ponieważ poświęcenie jednej osoby, by ocalić pięć innych, to działanie w imię „większego dobra”, maksymalizacja użyteczności to w zasadzie minimalizacja nieuniknionych strat. W drugim natomiast przypadku większość ludzi odpowiada, że nie zepchnęłaby innego człowieka, nie zabiłaby go. Podejmuja więc rozwiązanie deontologiczne, nie złamaliby podstawowej zasady moralnej nawet $\mathrm{w}$ imię wyższego dobra. $\mathrm{W}$ obu przypadkach decyzja jest zwiąana ze złamaniem moralnego zakazu krzywdzenia innych (w tym przypadku nawet zabicia innego człowieka), różnica pomiędzy nimi polega jednak na osobowym albo bezosobowym pogwałceniu norm ${ }^{20}$.

Joshua Greene wykorzystał metody obrazowania pracy mózgu za pomoca funkcjonalnego rezonansu magnetycznego (fMRI), by sprawdzić, co napędza różne rozwiązania dylematów moralnych. Wraz ze współpracownikami wymyślił szereg historyjek, w których występowała bezpośrednia, osobista krzywda, zazwyczaj wyrządzana z jakiegoś uzasadnionego powodu, natomiast inne sytuacje dotyczyły krzywdy wyrządzanej bezosobowo, podobnie jak w dylemacie wagonika. W tym celu Greene zamierzał sprawdzać, czy badani dokonywaliby wyborów utylitarnych, czy deontologicznych i jak wtedy zaangażowany byłby mózg. Zauważył, że formułując sądy deontologiczne, ludzie kierują się instynktownymi odczuciami (zaobserwował też przypływ początkowego przerażenia u badanych podczas wyobrażania sobie sytuacji, w których wyrządzają komuś krzywdę osobiście), aktywizowały się wtedy obszary mózgu związane z emocjami i rozpoznaniem społecznym (np. przyśrodkowa kora przedczołowa). Natomiast dylematy opowiadajace o krzywdzie bezosobowej były bardziej dogłębnie przemyślane, ponieważ nie wiązały się z takimi emocjami, podczas ich rozważania swoją aktywność zwiększały obszary mózgu związane z rozumowaniem abstrakcyjnym i rozwiązywaniem problemów (grzbietoboczna kora przedczołowa i płat ciemieniowy) badani mogli swobodnie przeanalizować różne możliwości i wybrać rozwiązanie utylitarne. Na tej podstawie Greene ze współpracownikami zaproponował model oparty na dwóch systemach. System pierwszy jest automatyczny, intuicyjny, wyczulony na emocje i szybki. Wywołuje szybkie reakcje na pojawiające się emocje i prowadzi do ocen opierających się na prostych zasadach moralnych (np. emocje związane z doznawaniem krzywdy, jak gniew, prowadzą do odrzucenia rozwiązania utylitarnego, związanego z krzywdzeniem innych). Drugi system jest refleksyjny, wolniejszy i bardziej wyczulony na konsekwencje ${ }^{21}$.

${ }^{20}$ J. Greene, L. Nystrom, A. Engell, J. Darley, J. Cohen, The neural bases of cognitive conflict and control in moral judgment, „Neuron” 44(2), 2004, s. 389-400.

${ }^{21}$ J. Greene, L. Nystrom, A. Engell, J. Darley, J. Cohen, The neural bases of cognitive conflict..., s. 389-400. Również Kahneman w swojej najnowszej książce pt. Pułapki myślenia. O myśleniu szybkim i wolnym (Poznań 2012) opisuje, jak o naszym myśleniu decydują dwa systemy: 
$\mathrm{Na}$ tej podstawie coraz bardziej popularnym przekonaniem wśród psychologów moralności staje się to, że utylitarne osądy moralne są traktowane jako oparte na racjonalnym rozumowaniu moralnym, podczas gdy rozstrzygnięcia deontologiczne są osądami emocjonalnymi, którym towarzyszy jedynie moralna racjonalizacja, uzasadnianie wcześniej podjętej decyzji ${ }^{22}$. W ten sposób, gdy osądy moralne odbiegają od utylitarnych, niektórzy psychologowie moralności, jak np. Cass Sunstein, mówią o tym, że były one oparte na heurystykach, co przecież prowadzi do zniekształceń i błędów oceny. Jonathan Baron i Ilana Ritov stwierdzili nawet wprost: „decyzje podejmowane na bazie zasad deontologicznych zazwyczaj nie prowadzą do najlepszych rezultatów"23.

Takie przyjęcie podejścia utylitarnego jako standardu normatywnego może oznaczać, że większość ludzi często jest moralnie zła, skoro jak pokazują badania Johna Mikhaila, 90\% osób odrzuca utylitarne rozwiązanie dylematu mostka. Oznaczałoby to, że rozstrzygnięcia moralne są nawet bardziej podatne na błędy poznawcze niż inne formy oceniania. Czy osoby, które wybierają utylitarne rozwiązania, są optymalnymi sędziami moralności? Czym się charakteryzuje te $10 \%$ osób, które wybierają utylitarne rozwiązanie wspomnianego dylematu mostka? Z jednej strony można zauważyć, że sa to osoby, które przy podejmowaniu decyzji moralnych preferuja racjonalna deliberację. Z drugiejże to samo deliberatywne rozumowanie, które wiąże się z przyjmowaniem utylitarnych rozwiązań, jest utrudnione, gdy decyzje sa podejmowane pod presja czasu czy w sytuacjach zwiększonego obciążenia poznawczego, np. wtedy gdy badani jednocześnie dokonują oceny moralnej i wykonują zadanie polegajace na zapamiętywaniu dłuższego ciagu liczb ${ }^{24}$.

Z kolei Daniel Bartels zauważył, że pomiędzy ludźmi występują różnice, jeśli chodzi o stopień, w jakim doświadczają oni silnych intuicji, zdolności do tworzenia dla swoich ocen uzasadnień oraz ich argumentowania (i otwartości na argumenty innych) ${ }^{25}$. Wyniki badań tego autora pokazuja, że osoby wybierające rozwiązania utylitarne to bardziej racjonalne jednostki - maja lepszą pamięć roboczą i w większym stopniu charakteryzuje ich myślenie deliberatywne podczas rozwiązywania problemów. Ale czy to oznacza, że osoby te potrafią zapanować nad emocjami, które nie pozwalają nam na skrzywdzenie innej osoby, czy jak sugerują Daniel Bartels i Dawid Pizarro, może nie sa

pierwszy szybki, intuicyjny i emocjonalny oraz drugi wolniejszy, ale działający w sposób bardziej logiczny.

22 Zob. J. Baron, I. Ritov, Protected values and omission bias as deontological judgments, „Psychology of Learning and Motivation” 50, 2009, s. 133-167; J. Greene, S. Morelli, K. Lowenberg, L. Nystrom, J. Cohen, Cognitive load selectively interferes with utilitarian moral judgment, „Cognition” 107, 2008, s. 1144-1154.

23 C. Sunstein, Moral heuristics, „Behavioral and Brain Sciences” 28(4), 2005, s. 531-573.

${ }_{24}$ Zob. J. Mikhail, Universal moral grammar: theory, evidence and the future, „Trends in Cognitive Science” 11(4), 2007, s. 143-152. Także: J. Greene, S. Morelli, K. Lowenberg, L. Nystrom, J. Cohen, Cognitive Load Selectivity..., s. 1144-1154; D. Cummins, R. Cummins, Emotion and deliberative reasoning in moral judgment, „Frontiers in Psychology” 3, 2012, s. 1-16.

${ }_{25}$ Zob. D. Bartels, Principled moral sentiment and the flexibility of moral judgment in decision making, „Cognition” 108, 2008, s. 381-417. Także zob. M. Koenigs, L. Young, R. Adolphs, D. Tranel, F. Cushman, M. Hauser, A. Damasio, Damage to prefrontal cortex increases utilitarian moral judgmnets, „Nature” 446(7138), 2007, s. 908-911. 
zdolne do ich odczuwania? Autorzy ci zauważyli, że osoby mające utylitarne preferencje charakteryzuja się cechami typowymi dla osobowości psychopatów: niską empatia, bezdusznością (deficyt przeżywania emocji), nieumiejętnością wyzbycia się dążenia do doraźnych przyjemności, impulsywnością oraz agresywnością przy braku wyrzutów sumienia ${ }^{26}$. W pewnym stopniu jest to zbieżne z wynikami badań nad osobami z uszkodzeniami mózgu dotyczacymi obszaru odpowiedzialnego głównie za emocje, którzy to pacjenci częściej wybierali utylitarne rozwiązania niż osoby zdrowe (tj. te, które nie doznały takich uszkodzeń) ${ }^{27}$.

W ostatniej dekadzie $\mathrm{w}$ dużym stopniu pod wpływem licznych badań J. Greene'a, coraz bardziej popularne staje się podejście dualne do procesu oceniania, które opera się na założeniu, że dychotomia pomiędzy poznaniem a emocjami jest fałszywa, ponieważ proces przetwarzania informacji obejmuje zarówno wyższe procesy poznawcze, tj. świadome rozumowanie, jak i niższe procesy poznawcze, jak np. odpamiętywanie, spostrzeganie, a emocje sa jedna $\mathrm{z}$ form przetwarzania informacji. W dylemacie mostka pierwotna, intuicyjna reakcja jest odmowa zepchnięcia przypadkowego przechodnia, chociaż niektóre osoby dokonują przemyśleń na temat konsekwencji i zmieniają zdanie. Jednakże taka intuicja może nie występować (lub występować na korzyść rozwiązania utylitarnego), gdy wchodzi w grę rozwiązywanie dylematu wagonika mniej angażującego emocjonalnie ${ }^{28}$. Silne reakcje afektywne angażuja, jak było to wyżej wspomniane, inne obszary mózgu niż te, które są aktywowane przy deliberatywnym podejmowaniu decyzji. Gdy nie ma wstępnej, silnej reakcji afektywnej, przeważa rozumowanie deliberatywne. Gdy występuje konflikt pomiędzy tymi obszarami, jest to rozpoznawane przez mózg, który sygnalizuje potrzebę kontroli poznawczej - wszystko zależy od tego, czy obszar odpowiedzialny za rozumowanie na ten sygnał zareaguje, wtedy wynikiem jest wybór deliberatywnego systemu, jeśli nie, ocenę wyznacza pierwotna reakcja emocjonalna.

Jak pisał J. Haidt, formułowanie ocen moralnych jest procesem poznawczym tak samo jak dokonywanie wszelkich innych ocen. Sa dwa rodzaje poznania: intuicje, czyli szybkie, automatyczne oceny moralne, i rozumowanie, oparte na języku, zatem intuicje sa formą poznania, tyle że nie są rozumowaniem. Badania neurobiologów prezentują liczne dowody na to, że podczas dokonywania ocen moralnych, takich jakie dokonujemy na co dzień, rolę odgrywa zarówno rozum, jak i emocje w sposób zintegrowany, wchodzą one ze sobą w rozmaite interakcje. Przykładem mogą być badania Paxtona i Greene’a, którzy przedstawiali badanym szereg dylematów moralnych do ocenienia, znanych z innych badań, takich jak np. jednorazowy kazirodczy seks pomiędzy dorosłym rodzeństwem, o którym nikt postronny nie miał możliwości się dowiedzieć, dokonany za obopólną zgodą. Następnie autorzy prezentowali argumenty, za pomocą których próbo-

\footnotetext{
${ }^{26}$ Zob. D. Bartels, D. Pizarro, The mismeasure of morals: antisocial personality traits predict utilitarian responses to moral dilemmas, „Cognition” 121, 2011, s. 154-161.

${ }_{27}$ Zob. A. Moore, B. Clark, M. Kane, Who shalt not kill? Individual differences in working memory capacity, executive control, and moral judgment, „Psychological Science” 19(6), 2008, s. 549-557.

${ }^{28}$ Zob. szerzej: J. Greene, S. Morelli, K. Lowenberg, L. Nystrom, J. Cohen, Cognitive Load Selectivity..., s. 1144-1154.
} 
wali zmienić dokonane przez badanych rozstrzygnięcia (utylitarne - deontologiczne). Argumenty te były dwojakiego rodzaju - słabe bądź silne, wymagające poważniejszej refleksji. Badanie dokonane z zastosowaniem neuroobrazowania (fMRI) pokazało, że szybkie przypływy afektu trwają krócej niż dwie minuty, więc gdy badani mieli czas na to, by się zastanowić nad rozwiązaniem (zmuszeni do dłuższego myślenia nad silnym argumentem), stawali się dużo bardziej tolerancyjni. Osoby, którym przedstawiano słabe argumenty, nadal potępiały naruszenie zasad moralnych, natomiast osoby, które miały czas na samodzielna refleksję, częściej dokonywały oceny sprzecznej z początkową intuicja. Napawa to nieco optymizmem, gdyż pokazuje, że istnieją pewne „przełączniki”, które pozwalają na większe zaangażowanie rozumowania w określonych sytuacjach, w których tego szczególnie oczekujemy ${ }^{29}$.

\section{ZAKOŃCZENIE}

Dokonania współczesnej psychologii moralności podpowiadają nam, że formułując oceny moralne, popełniamy wiele błędów, nie tylko gdy posługujemy się heurystykami, ale zwłaszcza wtedy gdy opieramy się w swych ocenach na intuicjach. Zaangażowania emocji przy dokonywaniu ocen moralnych nie da się zakwestionować w świetle wyników przeprowadzonych w ostatnich latach badań, wskazujących na nasze ograniczone możliwości poznawcze do rozwiązywania problemów moralnych. Pytanie pozostaje tylko, jak ważna pełnia one (a zwłaszcza intuicje) rolę. Jak mówi bowiem stare porzekadło: „emocje przyćmiewają rozum". Jeśli intuicje i rozumowanie występują naprzemiennie, a poszczególne obszary mózgu są aktywowane w różnym czasie, oznacza to, że automatyczne i kontrolowane operacje poznawcze konkuruja ze sobą o kontrolę nad reakcją danej osoby oraz że przez większość czasu deliberatywne osaady pozostaja zakotwiczone przez pierwotne wrażenia. Zazwyczaj ludzie sa nieświadomi tego, co wpływa na ich oceny moralne, można zatem spodziewać się, że również sędziowie mogą być nieświadomi tego, co powoduje ich osądy moralne, prowadząc do sformalizowanych decyzji, błędnie wierząc jednocześnie, że wyjaśnienia dokonywane ex post były przyczyną. Intuicje pełnią ważna rolę w dokonywaniu ocen moralnych również w przypadku osób wykonujących zawody prawnicze, od których oczekuje się, by opierały się na rozumowaniu, obiektywnym rozpatrywaniu różnych argumentów i przezwyciężały intuicje. Psychologia moralności, wykorzystując wyniki badań neurobiologów, w pewnym przynajmniej zakresie, może w tym pomóc.

dr hab. Teresa Chirkowska-Smolak

Uniwersytet im. Adama Mickiewicza w Poznaniu

chirko@amu.edu.pl

prof. dr hab. Marek Smolak

Uniwersytet im. Adama Mickiewicza w Poznaniu smolak@amu.edu.pl

${ }^{29}$ Zob. J. Greene, R. Sommerville, L. Nystrom, J. Darley, J. Cohen, An fMRI investigation of emotional engagement in moral judgment, „Science” 293(5537), 2001, s. 2105-2108. 
MORAL ASSESSMENTS IN JUDICIAL REASONING

Sum mary

There are two questions posed in this text: (i) does the formulation of moral assessments by judges require from them any special moral competences and (ii) does the moral reasoning have a character of rational reasoning. Answering the first question we claim that when it comes to formulating moral assessments, judges do not have any special moral competences to adjudicate in difficult moral dilemmas. Thus there is no reason to state that moral thinking experiments which are an inseparable element of a judge's reasoning process, allow to adopt a thesis that the reasoning of judges is morally better or more moral than the reasoning of other entities operating in the public sphere. Answering the second question, we believe that since people are generally unaware of what influences their moral judgements, it may also be so that the judges may not know what makes them adopt and pursue certain moral judgements, when they believe, erroneously, that their decisions have been rationally made. Intuition plays an important role in the making of moral judgements, also when it comes to the legal profession, since the latter are expected to base their attitudes on rational reasoning and an objective consideration of differing arguments. 